\title{
Manda Sütlerinde ICP-MS ile Metal ve Ağır Metal Seviyelerinin Belirlenmesi $^{\#}$
}

\author{
Recep KARA ${ }^{1 *}$, Ulaş ACARÖZ ${ }^{1}$, Zeki GÜRLER ${ }^{1}$, Sinan İNCE², Damla ARSLAN-ACARÖZ³ \\ 1 Afyon Kocatepe Üniversitesi, Veteriner Fakültesi, Grda Hijyeni ve Teknolojisi Anabilim Dal, Afyonkarabisar, Türkije \\ ${ }^{2}$ Afyon Kocatepe Üniversitesi, Veteriner Fakültesi, Farmakoloji ve Toksikoloji Anabilim Dal, Afyonkarahisar, Türkiye \\ ${ }_{3}^{3}$ Afyon Kocatepe Üniversitesi, Bayat Meslek Yüksek Okulu, Veteriner Sağllk ve Laboranthk. Bölümü, Afyonkarahisar, \\ Türkiye
}

"Bu çalşsma Afyon Kocatepe Üniversitesi, Bilimsel Arastırmalar Koordinasyon Birimi tarafindan "16.KARIYYER.138" proje numarast ile desteklenmiş ve "VET-Istanbul GROUP Congress 2017” de (Almaty) özet bildiri olarak sunulmustur.

*Corresponding author e-mail: recepkara@aku.edu.tr

ÖZ

Manda sütü, gıda teknolojisinde kullanılan sütler arasında en yüksek yağ oranına sahiptir. Günümüzde egzoz dumanı, atık su ile sulama, endüstriyel ve madencilik faaliyetleri gibi birçok nedenden dolayı toprakta önemli miktarda ağır metaller bulunabilmektedir. Bu metaller hayvan ve insan sağlı̆̆ını önemli ölçüde etkilemektedir. Bu çalışmanın amacı, Afyonkarahisar ilinden toplanan 50 çiğ manda sütünde $\mathrm{Al}, \mathrm{Cr}, \mathrm{Mn}, \mathrm{Fe}, \mathrm{Co}, \mathrm{Cu}, \mathrm{Zn}, \mathrm{As}, \mathrm{Se}$, $\mathrm{Mo}, \mathrm{Ag}, \mathrm{Cd}, \mathrm{Hg}$ ve $\mathrm{Pb}$ gibi metallerin/ağır metallerin varlı̆ı̆nı ve seviyesini ICP-MS ile belirlemektir. Süt örneklerinde Al, Cr, Mn, Fe, Co, Cu, Zn, Se ve Mo seviyesi sirasiyla 0,098; 0,001; 0,042; 0,331; 0,001; 0,076; 4,116; 0,011 ve 0,022 ppm olarak tespit edilmiştir. Ağır metallerin ( $\mathrm{Pb}, \mathrm{As}, \mathrm{Ag}, \mathrm{Cd}$ ve $\mathrm{Hg}$ ) ise tespit edilebilir limitin altında olduğu belirlenmiştir. $\mathrm{Bu}$ durum, manda yetiştiriciliğinin ve süt üretiminin ağır metal kontaminasyonundan uzak koşullar altında gerçekleştirildiğini göstermektedir. Ayrıca, diğer metal seviyelerindeki farklılıklar hayvanların beslenmesi ve çevresel koşullardan kaynaklanabilir.

Anahtar Kelimeler: Manda, Süt, Ağır Metal, Halk Sağllğ1

\section{Determination of Metal and Heavy Metal Residues in Buffalo Milk By ICP-MS}

\begin{abstract}
Buffalo milk has the highest value of fat ratio among milk used in food technology. Today, a significant amount of heavy metal found in the soil due to many reasons such as exhaust fumes, wastewater irrigation, industrial and mining activities. Therefore, the health of animal and human is significantly affected. The aim of this study was to determine the presence and contamination level of metals/heavy metals as $\mathrm{Al}, \mathrm{Cr}, \mathrm{Mn}, \mathrm{Fe}, \mathrm{Co}, \mathrm{Cu}, \mathrm{Zn}$, $\mathrm{As}, \mathrm{Se}, \mathrm{Mo}, \mathrm{Ag}, \mathrm{Cd}, \mathrm{Hg}$, and $\mathrm{Pb}$ in 50 raw buffalo milk samples obtained from Afyonkarahisar by using ICPMS instrument. Contamination level of milk samples with $\mathrm{Al}, \mathrm{Cr}, \mathrm{Mn}, \mathrm{Fe}, \mathrm{Co}, \mathrm{Cu}, \mathrm{Zn}, \mathrm{Se}$, and $\mathrm{Mo}$ was detected as $0.098,0.001,0.042,0.331,0.001,0.076,4.116,0.011$, and $0.022 \mathrm{ppm}$ respectively. In addition, contamination level of $\mathrm{Pb}, \mathrm{As}, \mathrm{Ag}, \mathrm{Cd}$, and $\mathrm{Hg}$ was determined under LOD. This suggests that buffalo breeding and milk production are performed under suitable conditions preventing from heavy metal contamination. It is also assessed that the quantities and differences in other metal levels detected in the analysis may depend on the feeding of the animals and environmental conditions.
\end{abstract}

Keywords: Buffalo, milk, heavy metal, public health

To cite this article: Kara R. Acaröz U. Gürler Z. Ince S. Arslan-Acaröz D. Manda Sütlerinde ICP-MS ile Metal ve Ağrr Metal Seviyelerinin Belirlenmesi. Kocatepe Vet J. (2018) 11(4): 468-471. 


\section{GİRIŞ̧}

Süt proteinleri biyolojik değeri yüksek proteinlerdir (Uzunöz ve Gülşen 2007). İnsanların yeterli ve dengeli beslenmesinde önemli bir yer teşkil eden süt, hayvansal kaynaklı yă̆, protein, laktoz, su, mineral, vitamin, enzim, organik asit ve iz elementleri içermektedir. Sütün bileşimi tür içinde ve türler arasında önemli ölçüde değişiklikler göstermektedir. Süt kompozisyonundaki farkllikllar fizyolojik, kalıtım, sağım sıklığı ve çevre faktörlerine bağlıdır (Renner ve ark. 1991, Ayar ve Demirulus 2000, Tekinşen 2000).

Manda sütü diğer sütlerle karşılaştırıldığında daha az su içeren, daha çok kuru madde (mineral, yağ, protein vb.) ihtiva eden besleyici bir gida maddesidir. Gıda teknolojisi açısından değerli bir süt olarak kabul edilen manda sütü kaymak, tereyağı, yoğurt ve peynir üretiminde kullanılmaktadır. Manda sütü kaymak bağlama özelliği ve renginin diğer sütlere göre daha beyaz olmas1 nedeniyle tercih edilmektedir. Ülkemizde mandacilik yaygin olarak Afyon, Samsun, Sinop, Balıkesir, Çorum, Amasya, Sivas, Muş ve Diyarbakır illeri ve çevrelerinde yapılmaktadır. (Metin 2001, Üçüncü 2004).

Ağır metal kirliliği son yllarda endüstriyel ve tarımsal kalkınma nedeniyle ciddi bir sağlık sorunu haline gelmektedir (Rajaganapathy ve ark. 2011). Krom, kadmiyum, kurşun ve civa gibi bazı elementlerin yüksek seviyelerinin neden olduğu toksisite iyi bilinmektedir (Llobet ve ark. 2003). Bunların içerisinde en zararlı ağır metaller kurşun, kadmiyum ve civadır. Biyolojik işlevleri olmayan bu metaller her derişimde zehirli olup, organizmada her organ ve dokuda farklı oranlarda birikebilmektedir (Zheljazkov ve Nielsen 1996, Dündar ve ark. 2012). Ayrıca bu ağır metaller düşük konsantrasyonlarda bile hemotoksik, nörotoksik ve nefrotoksik etkiler gösterebilmektedir (Al-Saleh ve ark. 2003).

Süt ve süt ürünlerinde metallerin bulunması ise, özellikle çevresel koșullara ve üretim prosesine bağlı olmaktadır (Anastasio ve ark. 2006). Dünyada ve ülkemizde özellikle inek ve manda sütü (Algan 2002, Özturan 2010, Khan ve ark. 2013, Bilgücü ve ark. 2016, Li ve ark. 2016; Roy ve ark. 2009, ElAnsary 2017) ile süt ürünlerinde (Temurci ve Güner 2006, Seğmenoğlu 2012, Kan 2015) ağır metal varlığına yönelik çalışmalar yapılmıştır. Yapılan bu çalışmada Afyonkarahisar ilinden toplanan çiğ manda sütlerinde bazı metal ve ağır metallerin varlığ ICP-MS ile araştırılarak halk sağllğ1 açısından risk oluşturup oluşturmayacağ1 değerlendirilmiştir.

\section{MATERYAL ve METOT}

\section{Materyal}

Bu çalş̧mada Afyonkarahisar ilinden Şubat-Mart 2017 tarihlerinde temin edilen 50 adet çiğ manda sütü örneği kullanılmıştır. Nitrik asit çözeltisinde 24 saat bekletilerek ağır metallerden arındırılmış numune kaplarına alınan örnekler soğuk zincir altında laboratuvara getirilmiştir.

\section{Metot}

\section{Mikrodalga Yakma}

Örnekleri yakma işlemi kapalı sistem mikrodalga yakma metoduna göre yapilmıştır. Bu amaçla; HP100 teflon kap içerisine $2 \mathrm{ml}$ çiğ süt alınarak üzerine $8 \mathrm{ml} \%$ 65'lik nitrik asit ve $1 \mathrm{ml} \% 30$ 'luk hidrojen peroksit eklenmiş ve $15-20$ dk bekletilmiştir. Yakma işlemi mikrodalga cihazında (Sineo MDS- 10; Çin) gerekli yakma programı $\left(130^{\circ} \mathrm{C}^{\prime}\right.$ de $10 \mathrm{dk}, 150^{\circ} \mathrm{C}^{\prime}$ de $5 \mathrm{dk}$ ve $\left.180^{\circ} \mathrm{C}^{\prime} \mathrm{de} 10 \mathrm{dk}\right)$ ayarlanarak uygulanmıştır. Daha sonra çözeltiler ultra distile su ile 50 ml'ye tamamlanarak filtre $(25 / 0,45 \mu \mathrm{m})$ edilmiştir. Elde edilen süzüntü okuma işleminde kullanılmıştır.

\section{Okuma-Değerlendirme}

Toplanan örneklerdeki metal-ağır metal (Al, Cr, $\mathrm{Mn}, \mathrm{Fe}, \mathrm{Co}, \mathrm{Cu}, \mathrm{Zn}, \mathrm{As}$, Se, Mo, Ag, Cd, Hg ve $\mathrm{Pb}$ ) seviyeleri ICP-MS (Agilent 7700x ICP-MS, Kaliforniya, ABD) ile belirlenmiştir. Tespit edilebilen minimum değer 0.0001 ppm'dir.

\section{BULGULAR ve TARTIŞMA}

Yapılan çalışmada manda sütlerinde tespit edilen metal seviyeleri Tablo 1'de verilmiştir. Bununla birlikte $\mathrm{As}, \mathrm{Ag}, \mathrm{Cd}, \mathrm{Hg}$ ve $\mathrm{Pb}$ ise tüm manda sütü örneklerinde tespit edilebilir limitin (0.0001 ppm) altında bulunmuştur.

Örneklerdeki ağır metal seviyelerinin $(\mathrm{Pb}, \mathrm{As}, \mathrm{Ag}$, $\mathrm{Cd}$ ve $\mathrm{Hg}$ ) Türk Gıda Kodeksi Bulaşanlar Tebliği'nde belirtilen limitlerin altında olduğu gözlenmiştir (Anonim 2011). Bu konuda ulusal ve uluslararası yapılan bazı çalışmalara bakıldığında; Algan (2002), Konya yöresinden topladığı inek sütlerinde ağı metal miktarlarını belirlemek amacı ile 61 örnekte ortalama $\mathrm{Pb}$ 0,0000001; Cd 0,0000388; As 0.0000839; Se 0.0000331 ve $Z n$ $0.0026681 \mathrm{ppm}$ düzeyinde saptadığını bildirmiştir. 
Tablo 1. Manda sütü örneklerinde tespit edilen bazı metal seviyeleri (ppm)

Table 1. The levels of some metals detected in buffalo milk samples ( $\mathrm{ppm}$ )

\begin{tabular}{cccccccccc}
\hline n:50 & Al & Cr & Mn & Fe & Co & Cu & Zn & Se & Mo \\
\hline Minimum & $<0,0001$ & $<0,0001$ & 0,004 & $<0,0001$ & $<0,0001$ & $<0,0001$ & 0,322 & $<0,0001$ & 0,005 \\
Maksimum & 1,443 & 0,015 & 0,246 & 3,883 & 0,002 & 0,476 & 9,644 & 0,034 & 0,057 \\
Ortalama & 0,098 & 0,001 & 0,042 & 0,331 & 0,001 & 0,076 & 4,117 & 0,011 & 0,022 \\
\hline
\end{tabular}

Temurci ve Güner (2006), Ankara'dan toplanan 36 süt örneğinde $\mathrm{Al}, \mathrm{Cd}, \mathrm{Cr}, \mathrm{Cu}, \mathrm{Fe}$, Ni miktarlarının sirasiyla ortalama $6 ; 0,114 ; 1,016 ; 4,300 ; 52,149$ ve 2,754 ppm, düzeylerinde olduğunu ve örneklerin hiçbirinde $\mathrm{Pb}$ tespit edemediklerini bildirmişlerdir. Özturan (2010) yaptığı çalışmada inek sütü örneklerinde $\mathrm{Ca}, \mathrm{Na}, \mathrm{K}, \mathrm{Mg}, \mathrm{Cu}, \mathrm{Fe}, \mathrm{Zn}, \mathrm{Pb}, \mathrm{Ni}$ ve Mn miktarların sırasıly;a; 1258,48; 415,51; 1768,58; 107,$33 ; 0,079 ; 0,640 ; 1,406 ; 0,031 ; 0,034$ ve 0,022 ppm düzeylerinde belirlemişlerdir. Kan (2015) Afyonkarahisar ilinin beş farklı noktasından topladı̆̆1 süt örneklerinden elde ettiği kaymak ve kaymakaltı sütlerinde ağır metal miktarları ICP-MS ile belirlemiştir. Elde edilen kaymak örneklerinde ortalama $\mathrm{Cr}, \mathrm{Mn}, \mathrm{Fe}, \mathrm{Co}, \mathrm{Ni}, \mathrm{Cu}, \mathrm{Zn}$, As, Se, Ba, ve $\mathrm{Pb}$ değerleri sirasılya: 0,$36 ; 0,56 ; 2,72 ; 0,08 ; 0,65$; 0,$09 ; \quad 8,27 ; \quad 0,14 ; \quad 0,94 ; \quad 0,17$ ve $0.01 \quad \mathrm{ppm}$ belirlemişken numunelerde $\mathrm{Mo}$, $\mathrm{Ag}$ ve $\mathrm{Cd}$ saptamamıştır. Bununla birlikte, kaymakaltı sütlerinde ise 0,$02 ; 0,13 ; 0,52 ; 0,02 ; 0,12 ; 0,02 ; 2,37$; 0,$04 ; 0,17 ; 0,04 ; 0,13 ; 0.01 \mathrm{ppm}$ düzeylerinde tespit ederken $\mathrm{Ag}$ ve $\mathrm{Cd}$ tespit edilmediğini rapor etmiştir. Bilgücü ve ark. (2016), Çanakkale'nin üç farklı noktasından farklı dönemlerde toplanan çiğ inek süt örneklerinde metal $(\mathrm{Mn}, \mathrm{Zn}, \mathrm{Cr}, \mathrm{Cu}, \mathrm{Co})$, ağır metal $(\mathrm{Cd}, \mathrm{Pb})$ ve mineral madde $(\mathrm{Al}, \mathrm{Ca}, \mathrm{K}$, $\mathrm{Na}, \mathrm{Fe}, \mathrm{Mg}$ ) düzeylerini İndüklenmiş Eşleşmiş Plazma Atomik Emisyon Spektroskopi (ICP-AES) ile belirlemişlerdir. Örneklerde $\mathrm{Cd}, \mathrm{Mn}$ ve $\mathrm{Pb}$ içerikleri bakımından dönemler arasında bir farklılık gözlendiğini, bölgeler arasında ise bir farkllilk görülmediğini bildirmişlerdir. Metal düzeylerinde bölgeden bölgeye farklilık belirlenirken, mineral madde düzeylerinde ise bir değişim olmadığını rapor etmişlerdir.

Roy ve ark (2009) Hindistan Haryana eyaletinin iki farklı bölgesinden topladıkları manda sütlerinde, $\mathrm{Pb}, \mathrm{Cd}, \mathrm{As}$ ve $\mathrm{Hg}$ seviyelerinin ortalamaların sirasiyla 1 . bölgede $0,048 \mathrm{ppm} ; 0,006 \mathrm{ppm} ; 21,13$ ppb ve $0,73 \mathrm{ppb} ; 2$. bölgede ise $0,090 \mathrm{ppm} ; 0,006$ ppm; $18,81 \mathrm{ppb}$ ve $0,43 \mathrm{ppb}$ olarak tespit etmişlerdir. Khan ve ark. (2013), Ekim 2010 Ocak 2011 arasinda toprak, yem ve inek sütü örneklerinde kurşun (Pb) miktarını belirlemek amaciyla birleştirilmiş atomik absorpsiyon spektrofotometre ile grafit firın tekniğini kullanmışlardır. Örneklerde Pb konsantrasyonlarını toprakta $1,2-3,5 \mathrm{ppm}$, yemde $0,33-0,70 \mathrm{ppm}$ ve sütte $0,018-0,050 \mathrm{ppm}$ aralığında tespit etmişler ve bu örneklerde $\mathrm{Pb}$ konsantrasyonunun zamana bağlı olarak azaldığını bildirmişlerdir. Li ve ark. (2016) yaptıkları çalşsmada, 2012-2014 yılları arasında Çin'in Tangshan şehrinden doğrudan çiftliklerden topladıkları toplam 205 çiğ inek sütlerinde ağır metallerden $\mathrm{As}, \mathrm{Pb}, \mathrm{Cr}$ ve $\mathrm{Hg}$ düzeylerini belirlemeyi amaçlamışlardır. Analiz edilen Örneklerdeki ağır metal düzeylerinin Çin Hükümeti tarafindan belirlenen maksimum limitleri aşmadığını ve dolayısıyla çiğ sütlerin insan sağlığ1 açısından nispeten güvenli olduğunu bildirmişlerdir. El-Ansary (2017) Misır'da topladığ1 12 adet manda sütü örneğinde atomik absorbsiyon spektrofotometresi kullanarak Cd seviyesini ortalama 0,3084 ppm, $\mathrm{Pb}$ seviyesini ortalama 0,05878 ppm seviyesinde tespit emiştir.

$\mathrm{Bu}$ çalışmada analize alınan manda sütlerinden elde edilen ağır metal varllğı bulguları ile diğer araştırmacıların sonuçları benzerlik göstermektedir. Çalışmada manda sütlerinde $\mathrm{Al}, \mathrm{Cr}$, $\mathrm{Mn}, \mathrm{Fe}, \mathrm{Co}, \mathrm{Cu}, \mathrm{Zn}$, Se ve Mo gibi metallerin farklı seviyelerde tespit edilmesinde hayvanlara verilen rasyonun veya meraların metal içeriği ile ilgili olabileceği düşünülmektedir. Hatta bazı iz elementleri ( $\mathrm{Fe}, \mathrm{Co}, \mathrm{Zn}, \mathrm{Se})$ içermiş olması sütün besleyici değerini ortaya koymaktadır. Bununla birlikte $\mathrm{Pb}, \mathrm{As}, \mathrm{Ag}, \mathrm{Cd}$ ve Hg'nin tespit edilebilir limitin altında olması, manda sütü tüketiminin ağır metaller yönünden insan sağlığ1 açısından risk oluşturma ihtimalinin düşük olduğu görülmektedir.

\section{SONUÇ}

Sonuç olarak, analize alınan manda sütlerinde $\mathrm{Al}$, $\mathrm{Cr}, \mathrm{Mn}, \mathrm{Fe}, \mathrm{Co}, \mathrm{Cu}, \mathrm{Zn}$, Se ve Mo miktarları farklı seviyelerde tespit edilirken, $\mathrm{Pb}, \mathrm{As}, \mathrm{Ag}, \mathrm{Cd}$ ve $\mathrm{Hg}$ ise saptanamamıştır. Buna göre toplanan süt örnekleri Türk Gida Kodeksi'ne uygun bulunmuştur. Özellikle örneklerde $\mathrm{Pb}, \mathrm{As}, \mathrm{Ag}, \mathrm{Cd}$ ve $\mathrm{Hg}$ gibi risk oluşturabilen metallerin tespit edilmemiş olması sütlerin ağır metal yönüyle halk sağlığ1 açısından risk oluşturmayacağ görülmektedir. $\mathrm{Bu}$ riskli ağır metallerin süt ve ürünlerindeki konsantrasyonunun bu seviyede kalabilmesi için bilinçli ve kontrollü bir üretimin devam ettirilmesi gerekmektedir. Bu bağlamda ayrıca çiftçi ve işletmecilerin bilgilendirilmesi, 
eğitimlerin düzenlenmesi ve son olarak rutin kontrollerin düzenli bir şekilde devam etmesi tavsiye edilmektedir.

\section{KAYNAKLAR}

Algan G. Konya Yöresi Süt Örneklerinde bazı ağır metallerin incelenmesi, Selçuk Üniversitesi, Sağlık Bilimleri Enstitüsü, Yüksek Lisans Tezi. 2002.

Al-Saleh I, Shinwari N, Mashhour A. Heavy Metal Concentrations in the Breast Milk of Saudi Women. Biological Trace Element Research, 2003; 96(1-3): 21-37.

Anastasio A, Caggiano R, Macchiato M, Paolo C, Ragosta M, Paino SV, Cortesi M L. Heavy Metal Concentrations in Dairy Products from Sheep Milk Collected in Two Regions of Southern Italy. Acta Ve. Scand, 2006; 47: 69-74.

Anonim. Türk Gıda Kodeksi Bulaşanlar Yönetmeliği, Say1 : 28157, 29.Aralık.2011.

Ayar A. Demirulus H. Eğitim çağındaki gençlerin süt ve süt ürünleri tüketim alışkanlıklarının belirlenmesi üzerine bir araştırma. Gıda, 2000; 25(5): 371-376.

Bilgücü E. Kaptan B. Palabıyık İ. Öksüz Ö. The Effect of Environmental Factors on Heavy Metal and Mineral Compositions of Raw Milk and Water Samples. JOTAF/Tekirda ̌̆ Ziraat Fakültesi Dergisi, 2016; 13(4): 61-70.

Dündar MŞ. Altundağ H. Kaygaldurak S. Şar V. Acar A. Çeşitli endüstriyel atik sularda ağır metal düzeylerinin belirlenmesi. SAÜ. Fen Bilimleri Dergisi, 2012; 16(1): 6-12.

E1-Ansary MA. Determination of Heavy Metals Content (Cadmium and Lead) in Raw Cow's and Buffalo’s Milk. Int. J. Curr. Res. Biosci. Plant Biol. 2017; 4(8): 116-120.

Kan F. Afyon Manda Kaymağı ve Kaymakaltı Sütlerinde Bazı Ağır Metallerin ICP-MS ile Araştırılması. Afyon Kocatepe Üniversitesi, Sağlık Bilimleri Enstitüsü. Yüksek Lisans Tezi. 2015.

Khan ZI. Ahmad K. Bayat A. Mukhtar MK. Sher M. Evaluation of lead concentration in pasture and milk: A possible risk for livestock and public health. Pakistan Journal of Zoology, 2013; 45(1): 79-84.

Li A. Du R. Zheng B. Meng J. Zhang J. Xiang A. Zhang X. Qi B. Wu Y. Zhou X. Zhang Y. Dong L. Pang X. Determination of Heavy Metals in Raw Milk Produced in
Tangshan City, China. In MATEC Web of Conferences (Vol. 39). EDP Sciences, 2016.

Llobet JM, Falco G, Casas C, Teixido A, Domingo JL. Concentrations of Arsenic, Cadmium, Mercury and Lead in common foods and estimated daily Intake by children, adolescents, adult and seniors of Catalonia, Spain. J. Agric. Food Chem, 2003; 51: 838-842.

Metin M. Süt Teknolojisi, Sütün Bileşimi ve İşlenmesi. Ege Üniversitesi Mühendislik Fakültesi Yayınlar1 No: 33. Ege Üniversitesi Basımevi, 802 s., Bornova, İzmir. 2001.

Özturan K. Erzurum ve çevresinde üretilen süt ve süt ürünlerinin mevsimlere göre mineral madde ve ağır metal içeriği. Atatürk Üniversitesi Sağllk Bilimleri Enstitüsü, Doktora Tezi. 2010.

Rajaganapathy V, Xavier F, Sreekumar D, Mandal PK. Heavy Metal Contamination in Soil, Water and Fodder and their Presence in Livestock and Products: A Review. Journal of Environmental Science and Technology, 2011; 4: 234-249.

Renner E. Schaafsma G. Scott KJ. Micronutrients in milk. Food Science and Technology Abstracts, 1991; 23(11): 11-17.

Roy D. Bharathidhasan S. Mani V. Kaur H. Kewalramani N. Heavy Metal Contents in Cow and Buffalo Milk Samples from Haryana. Indian J. Anim. Nutr. 2009; 26(1): 29-33.

Seğmenoğlu MS. Türkiye'de Tüketime Sunulan Organik Ve Geleneksel Süt Ve Süt Ürünlerinin Baz1 Metal Düzeyleri Yönünden Karşılaştırılması. Ankara Üniversitesi, Sağlık Bilimleri Enstitüsü, Doktora Tezi. 2012.

Tekinşen OC. Süt Ürünleri Teknolojisi 3. Bask1 Selçuk Üniversitesi Basımevi, Konya. 2000.

Temurci H. Güner A. Ankara'da tüketime sunulan süt ve beyaz peynirlerde ağır metal kontaminasyonu., Atatürk Üniversitesi Vet. Bil. Derg. 2006; 1(1-2): 20-28.

Uzunöz M. Gülşen M. Üniversite öğrencilerinin süt ve süt ürünleri tüketim alıșkanlıklarının belirlenmesi. Gida Teknolojileri Elektronik Dergisi 2007; 3: 15-21.

Üçüncü M. A'dan Z'ye Peynir Teknolojisi. Cilt II. Ege Üni. Mühendislik Fak. Gıda Müh. Bölümü, 1233 s., İzmir. 2004.

Zheljazkov VD. Nielsen NE. Effect of heavy metals on peppermint and cornmint. Plant and Soil. 1996; 178 (1): 59-66. 